\title{
ブロックマットに使用した合成織維製織布の地中における 長期耐久性について
}

\section{概 要}

ブロックマットに使用したPE 及びPESよク成る合成䋞維製織布を施工後1〜 10年経て地中より掘り出し、引張試験によりその長期耐久性を調查した。 その結果、地中での長期耐力は当初の $76 \%$ 97\%に落ちているものの経過時間 との関係は必ずしも明らかではなかった。

Woven geotextiles made of PE and PET were used for concrete blockmats, and were investigated after 1 to 10 years to see its long term durabirity by taking out from the underground.

The tensile strength test results showed about 3 to $24 \%$ decrease compared with the initial tensile strength. But it did not show the clear inclination between the long term durability and exposure time. 


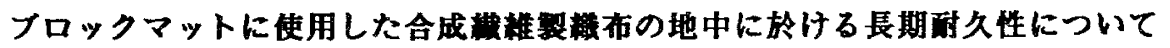

旭化成建材(株) 大阪土木資材部 河田秀雄

はしめに

ブロックマットとは、合成幽維製俴布の上に有孔で特殊な形状をしたコンクリートブロックを工場で 貼付しマット状にした、護岸・法面保绕資材である。

本報告は、このコンクリート製ブロックを連結してマット状にするために使用した合成維維製織布の 地中における長期耐久性について、施工後十分な期間を経て一部掘り出し、引張試駼により調查したも のである。

ブロックマットに使用された合成維維製織布の材筫は、ボリエステルおよびボリエチレンであり、調 查時期は数設後 1 年〜 10年である。

1. 試駼体

1)プロックマッ上

图ー1にブロックマットに使用するコンクリートブロック1個の標準寸法を示す。ブロックは\#形を した有孔で、有孔平は䄪30\%であり、その重量は䄪 $5 \mathrm{~kg} /$ 個である。

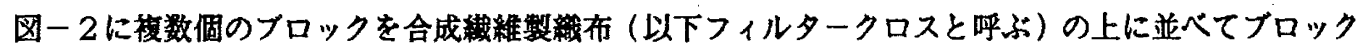
マットとした場合の標準寸法を示す。コンクリートブロックとフィルタークロスとはエポキシ樹脂によ り接着される。
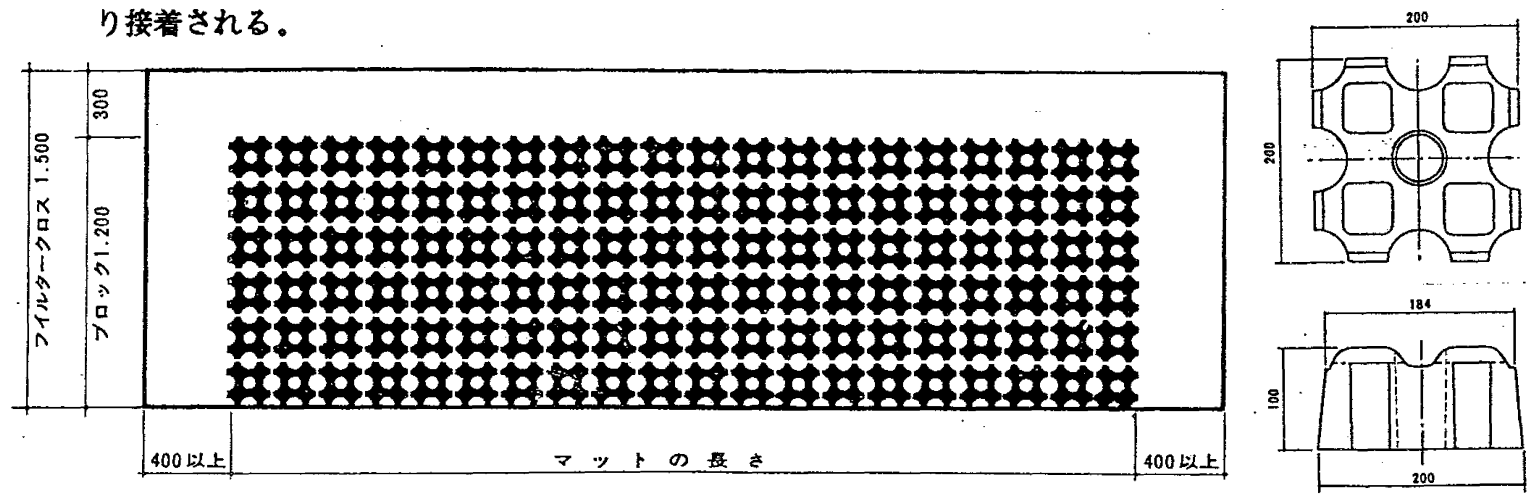

図一2 ブロックマットの標準図

2) フィルタークロ즈

図ー 1 ブロックの標準仕様

フィルタークロスはポリエステルおよびポリエチレンの複合織布である。表一1にフィルタークロス の仕様を示す。また写真ー1にフィルタークロスの表面状帹を示す。写真の中で白い部分がホリエステ ルであり、粎 $5 \mathrm{~cm}$ の間隔で配面されている。黒い部分はボリエチレンである。ボリエステルは主として 強度部材として、ポリエチレンは主としてフィルター材としての機能をはなすように設計されている。 なお、フィルタークロスの引張強度は巾 $5 \mathrm{~cm}$ 当たり粎 $300 \mathrm{kgf} \sim 340 \mathrm{kgf}$ ある。

3) フロックマットの数設

ブロックマットは工場で製造された後、施工現場へ輸送され、専用の吊具を用いて所定位宣に教設さ れる。この吊上げ時にフィルタークロスに作用する最大張力は䄪 $50 \mathrm{kgf} / 5 \mathrm{~cm}$ である。写真ー 2 は敷設 
されるため、吊上げられた状態を示す。ブロックマット 相互の連結はマットの余端部に次のマットを重わ合わせ ることにより行なかれる。施工現場でブロックマットの 敷設が完了すると、次にブロックマットの有孔部に 客土する。客土はつィルタークロスを柴外線より保護 すると共に植生の䭎能を有する。

2、試験体のサンプリンダ

1、䳏駼体の採取位宣

試驗体は、過去に敷設したブックマットの上端 部のフィルタークロス部分を掘り出して啋取した。

表一1フィルタークロスの仕栐

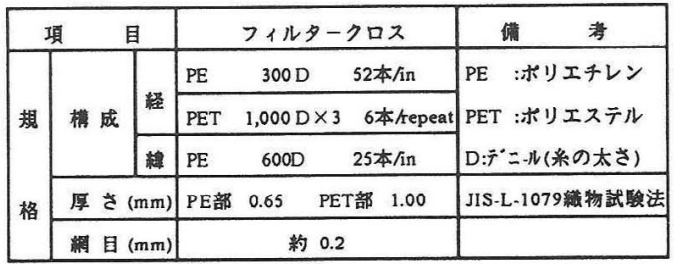

図ー3に採取位冨を○印で示す 探取した試験体の寸法は粎 300 $\mathrm{mm} \times 300 \mathrm{~mm}$ あった。

2)、試驗体の操取場所および敷 設期閪

表ー 2 に試驗体の敷設されて いた場所、敷設日、敷設期間を 示す。

\section{3、試驗左法および試駼結果}

\section{1)、試験方迲}

啋取した試験体より巾 $50^{\mathrm{mm}} \times$ 長さ300 $\mathrm{mm}$ の引張試験体を三体作 製し、JIS-L-10 96 ラベルドス トッリプ法 に従って引張 試験を行なっ た。

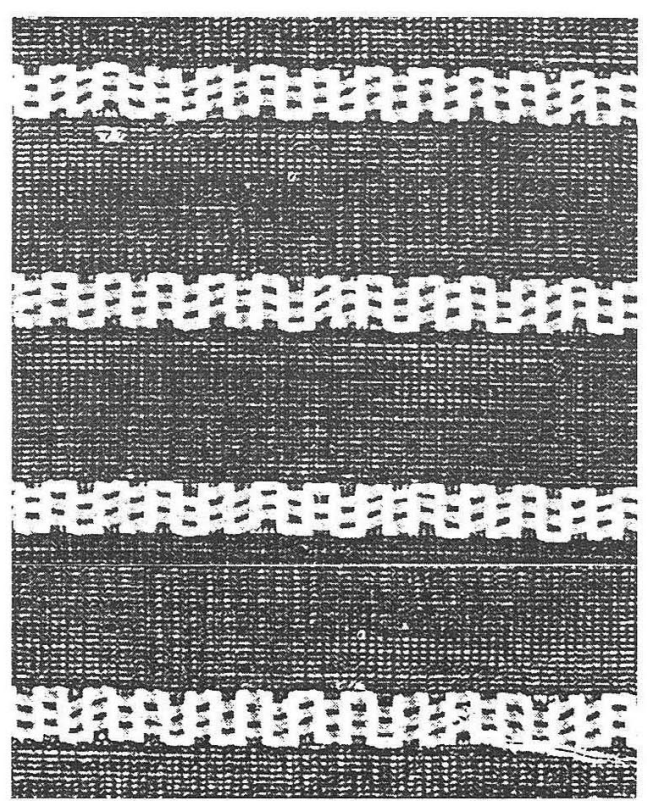

写真 -1 フィルタークロス

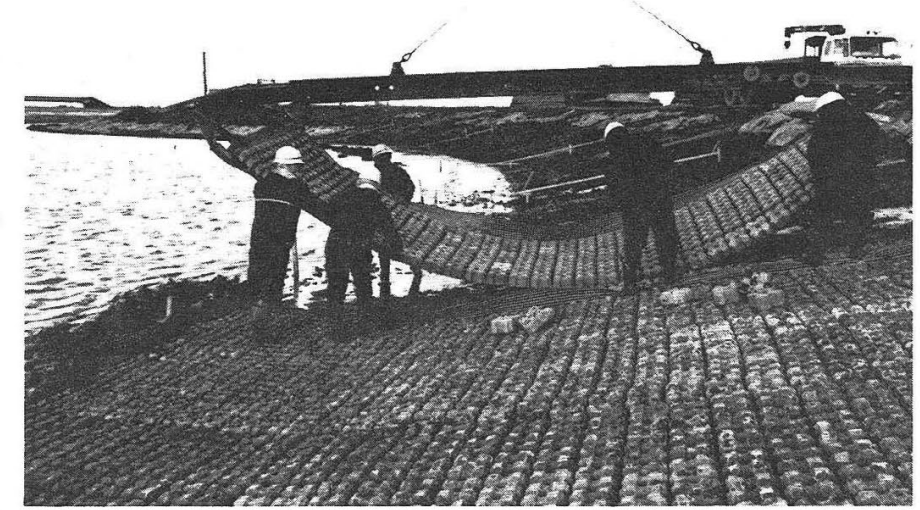

写真ー 2 ブロックマットの敷設

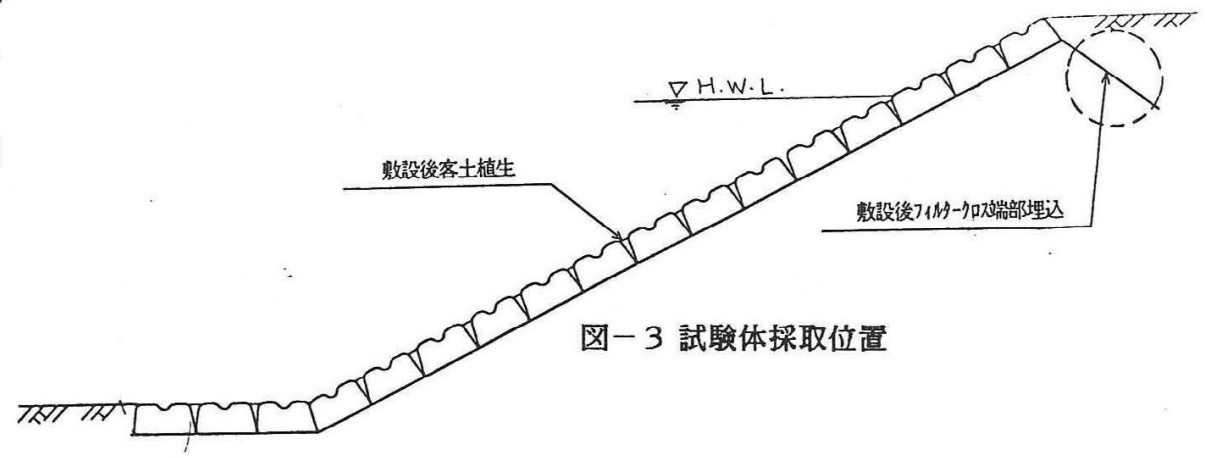




\section{2)、試駩結果}

引張試駇結果

を表一 2 中に併記

する。また、数設

期間と引張強度の

関保を図 -4 に示

す。

(kgf/5cm)

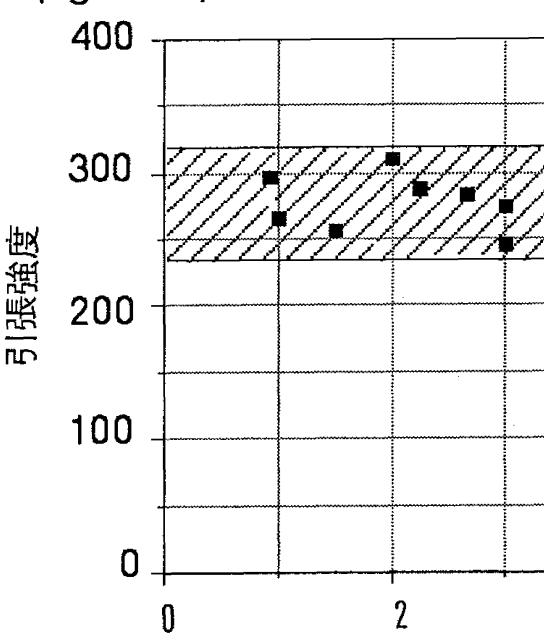

\section{4、試駩結果の考察}

1、フイルタークロスの長期酎久性について

\begin{tabular}{|c|c|c|c|c|c|}
\hline No. & 場 所 & 用 途 & 数敖時期 & 柽過年数 & 柅張搏度 $(\mathrm{kgf} / 5 \mathrm{~cm})$ \\
\hline 1 & 莰城婪新治郡 & 河川低水護岸 & 昭和 50年 6 月 & 3 年 & 275 \\
\hline 2 & 茨城县筑波郡 & 河川低水鈛岸 & 昭和 50 年 10 月 & 2 年 8 ケ月 & 283 \\
\hline 3 & 要知県名古屋市 & 河川高水敖譩岸 & 昭和 52 年 2 月 & 8 年 & 244 \\
\hline 4 & 茨娍県竜ヶ崎市 & 河川高水䧿㪍 & 略和 53 年 7 月 & 2 年 3个月 & 288 \\
\hline 5 & 茨城県䄸教郡 & 水路境岸 & 略和 53 年 12 月 & 9 年9ケ月 & 274 \\
\hline 6 & 蚑阜県海津郡 & 河川低水隻岸 & 昭和 57 年 8 月 & 4 年 6 ケ月 & 300 \\
\hline 7 & 茨城婪岩井市 & 水路㒕岸 & 昭和 58 年 3 月 & 5 年 6 个月 & 272 \\
\hline 8 & 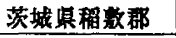 & 河川离水辌岸 & 昭和 58 年 9 月 & 5 年 & 268 \\
\hline 9 & 秓阜県海津郡 & 河川低水讙岸 & 昭和 59 年 2 月 & 3 年 & 245 \\
\hline 10 & 北海道小榑市 & 河林保墽 & 昭和 60 年 2 月 & 1 年 & 265 \\
\hline 11 & 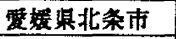 & 河川低水意崖 & 昭和 61 年 3 月 & 1 年 6ケ月 & 258 \\
\hline 12 & 兵庭堡加東郡 & 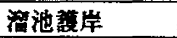 & 四召和 61 年 3 月 & 2 年 & 310 \\
\hline 13 & 大阪府堌市 & 河川高水護㟁 & 昭和 61 年 8 月 & 11ケ月 & 297 \\
\hline
\end{tabular}

表ー 2 試験体の採取場所および敷設期間

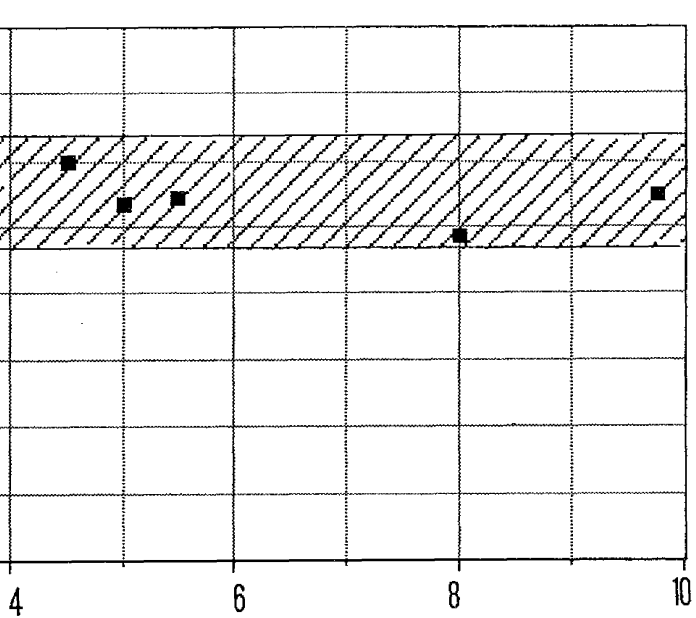

敷設後経過年数

图ー4に示すように敖設・埋設後、1 10年の地中におけるフィルタークロスの引張強度は、粎 245 〜310 kgf $/ 5 \mathrm{~cm} の$ 範囲にあり、また、この期間における経過年数と強度の相関は特に認められず、ほほ一 定範囲に分布している。

數設前のフィルタークロスの強度は約 $320 \mathrm{kgf} / 5 \mathrm{~cm}$ であるから、この期間における強度は初期の、76〜 97\%であることがわかる。

2) 常時応力との関係

敖設されたブロックマットとその下面の土が一体化し、相互間に移動がなければフィルタークロス に作用する常時引張店力はほぼゼロであると考えられる。しかし、急勾配な斜面に敷設した場合は フィルタークロスに常時の引張応力が作用していることも考えられる。この様な場合、全ブロック重 量(125kgf/m²)が全て引張応力としてフィルタークロスに作用したと仮定しても、その值は $50 \mathrm{kgf} / 5 \mathrm{~cm}$ 以下 である。一方、10年経過したフィルタークロスの引張強度は約 $250 \mathrm{kgf} / 5 \mathrm{~cm}$ 以上であったから、常時 芯力 $50 \mathrm{kgf} / 5 \mathrm{~cm}$ 対するフィルタークロスの安全率は5倍以上あると考えられる。 


\section{3)、既往の研究との比較}

G.Heerten`は海岸の堤防内に旅工された砂袋等からサンプリングを行ない、各種ジオテキスタイルの 25 年間の長期耐久性について調查している。

图一5および国一6は経遇年数と残留引張强度の比來について示したもので、図ー5は柴外線を受け

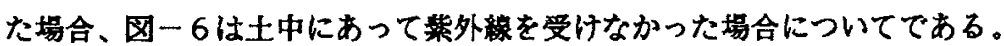

目一 5 、困-6

よりポリエチレン とボリエステルに ついてみると、柴 外線を受けるとそ の強度低下はかな ク大きいが、土中 にあって策外線を 受けない場合は15 年で20\%以下であ ることを示してい る。また、多くの 場合、1 年以内に 大半の低下が生じ 2 年目以降はほと んど低下していな いことも明らかで ある。

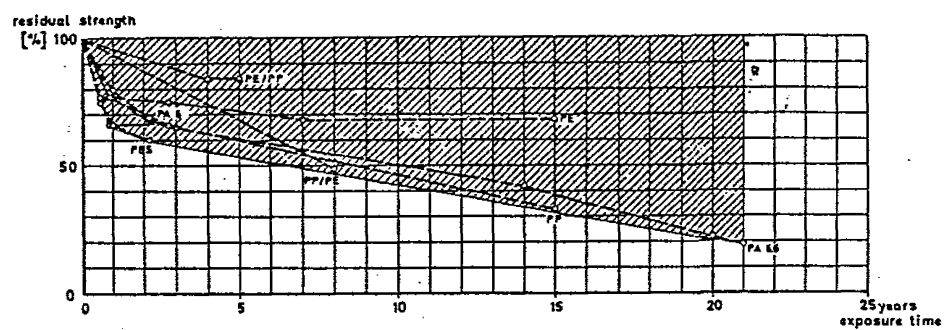

図 -5
Decrease of fabric strength, fabrics being unprotected by cover layers. PE, polyethylene; PP, polypropylene, PA 6, polyamide 6 (Perlon); PES, polyester.

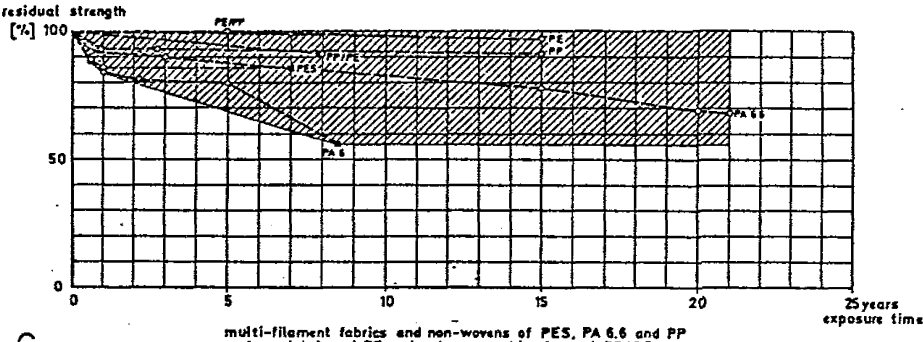

图 -6

Decrease of fabric strength, fabries being protected by cover layers. PE, polyethylene; PP, polypropylene; PA 6, polyamide 6 (Perlon); PES, polyester.

\section{5。あと方き}

本報告は、これまで数設したブロックマットの中からサンプリングを行ない、その長期耐久性につい て追跡調查を実施したものである。従って経過年数等必ずしも平均的に網羅されているとは言い難い。 また、データを解析する上でのフィルタークロスの製造条件、強度、施工条件等の初期条件が必ずしも 完全ではないので、十分な考察には至っていない。

今後、更にデー夕数を增し、定量的な考察を行なう必要があると考えている。

\section{6、引用文献}

*1).Geotextiles in Coastal Engneering - 25 Years Experience ;

G.Heerten; Geotextiles and Geomembranes $1(1984)$ pp 119-141

*2).Effect of High Levels of Alkalinity on Geotextiles - Part 1: $\mathrm{Ca}(\mathrm{OH})_{2}$ Solutions;

Yick Hales, Robert M.Koerner and Arthur E.Lord Jr ;

Geotextiles and Geomembranes 5 (1987) pp261-282

*3).Effect of High Alkalinity Levels onGeotextiles -Part 2: $\mathrm{NaOH}$ Solutions

Yick Hales, Robert M.Koerner and Arthur E.Lord Jr ;

Geotextiles and Geomembranes 5 (1987) pp295-305 